\title{
30. LATE CENOZOIC MAGNETOSTRATIGRAPHY OF DEEP SEA DRILLING PROJECT HOLE 603C, LEG 93, ON THE NORTH AMERICAN CONTINENTAL RISE OFF CAPE HATTERAS1
}

\author{
G. Canninga and J. D. A. Zijderveld, Paleomagnetisch Laboratorium "Fort Hoofddijk," Rijksuniversiteit Utrecht \\ and \\ J. E. van Hinte, Instituut voor Aardwetenschappen, Amsterdam²
}

\begin{abstract}
A geomagnetic polarity zonation has been determined for sediments from DSDP Hole $603 \mathrm{C}$, located on the continental rise off Cape Hatteras in the northwest Atlantic. The section recovered comprises lower Pliocene to Pleistocene contourites in which at least 15 geomagnetic polarity zones have been established. A sequence of seven successive polarity zones has been statistically correlated with the interval in the geomagnetic polarity time scale that ranges from the top of the Nunivak Subchron to the top of the Kaena Subchron. By extrapolation and deduction it can be concluded that the entire section probably embraces 17 geomagnetic polarity zones and represents that part of the geomagnetic polarity time scale that extends from the base of the Gilbert Chron to slightly above the Olduvai Subchron. The average sediment accumulation rate for the contourites has been estimated to be $10.1 \mathrm{~cm} / 10^{3}$ year.
\end{abstract}

\section{INTRODUCTION}

Deep Sea Drilling Project Site 603 is situated in the northwest Atlantic off Cape Hatteras, at the foot of the lower continental rise (Fig. 1). This study seeks to determine the late Neogene magnetostratigraphy of Site 603 and thus obtain a precise time scale for the study of the sedimentary sequence. Three holes drilled at this site penetrated Cenozoic sediment. Lower Pleistocene to Upper Cretaceous sediments were rotary drilled in Holes 603 and 603B, but core recovery for the upper Cenozoic in these holes was insufficient to establish a reliable magnetostratigraphy. In Hole $603 \mathrm{C}$, however, lower Pleistocene to lower Pliocene sediments were continuously cored by hydraulic piston coring (HPC) and the extended core barrel technique (XCB), providing adequate material for a magnetostratigraphic study. From this hole, green, muddy contourites of the Blake Ridge Formation were recovered (Jansa et al., 1979); an early Pleistocene to early Pliocene age was attributed to them by shipboard planktonic foraminiferal biostratigraphy (Site 603 chapter, this volume). Again according to planktonic foraminifers, the Pliocene/Pleistocene boundary (sensu Berggren and Van Couvering, 1974) is located at about $31 \mathrm{~m}$ sub-bottom, whereas the same boundary according to nannofossils (the base of the Helicosphaera selli Zone; Gartner, 1977) is at about $29 \mathrm{~m}$ sub-bottom.

Previous DSDP sites drilled near Site 603 (Sites 8, 105, 106, and 388; see Fig. 1) penetrated sediments that were mainly of early Tertiary to Mesozoic age; recovery of Neogene sediments was poor.

\footnotetext{
${ }^{1}$ van Hinte, J. E., Wise, S. W., Jr. et al., Init. Repts. DSDP, 93: Washington (U.S. Govt. Printing Office)

2 Addresses: (Canninga, Zijderveld) Paleomagnetisch Laboratorium "Fort Hoofddijk," Budapestlaan 17, 3584 CD, Utrecht, The Netherlands; (van Hinte) VU-Instituut voor Aardwetenschappen, P.O. Box 7161, 1007 MC, Amsterdam, The Netherlands.
}

\section{Sediments Examined in this Study}

The uppermost $91 \mathrm{~m}$ of Hole $603 \mathrm{C}$ was sampled using the HPC; thereafter drilling continued with the XCB to a total depth of $366 \mathrm{~m}$ sub-bottom. The cores taken by HPC are relatively undisturbed, with nearly complete recovery $(98.6 \%)$. Technical problems led to poor recovery from the first two XCB cores, so that there is a coring gap between 91 and $107 \mathrm{~m}$ sub-bottom, but recovery improved between 107 and $251 \mathrm{~m}$. Sediments from the upper part of this interval (107-170 m sub-bottom) are relatively undisturbed, whereas those between $170 \mathrm{~m}$ and $251 \mathrm{~m}$ sub-bottom show progressively greater disturbance with increasing depth. Below $251 \mathrm{~m}$ sub-bottom, all cores contain moderately to severely disturbed sediments. There are four gaps, each almost $10 \mathrm{~m}$ thick, in the core recovery between $251 \mathrm{~m}$ and $308 \mathrm{~m}$ sub-bottom. Between $308 \mathrm{~m}$ and the base of Hole $603 \mathrm{C}(366.0 \mathrm{~m})$, core recovery was continuous.

\section{METHODS}

On board ship, magnetostratigraphic samples were taken by pushing small $\left(7.5 \mathrm{~cm}^{3}\right)$ cylindrical plastic boxes 1 in. in diameter into the clay perpendicularly to the split face of the cores, using the orientation mark on the side of the boxes to indicate the top of the samples. Boxes were closed, sealed, and labeled immediately. In the lower part of the section, stronger plastic tubes, also $1 \mathrm{in}$. in diameter, had to be used because of the increasing stiffness of clays. Both the HPC and the $\mathrm{XCB}$ cores of Hole $603 \mathrm{C}$ have only a vertical orientation. A total of 399 samples was taken from 40 cores. Every 1.5 -m core section was sampled at approximately $41 \mathrm{~cm}$ and $121 \mathrm{~cm}$ below its top, so that throughout the interval studied the average distance between the samples was about $75 \mathrm{~cm}$.

All measurements were made on an ScT superconducting rock magnetometer at the Fort Hoofddijk Paleomagnetic Laboratory of the University of Utrecht. Initial measurements revealed the direction and intensity of the total natural remanent magnetization (NRM) of all samples (Figs. 2 and 3). Since the samples are oriented only to the split face of the cores, the magnetic polarity can be deduced only from the inclination of the remanence direction. In the upper part of the section (Fig. 2) negative (reversed polarity) and positive (normal polarity) 


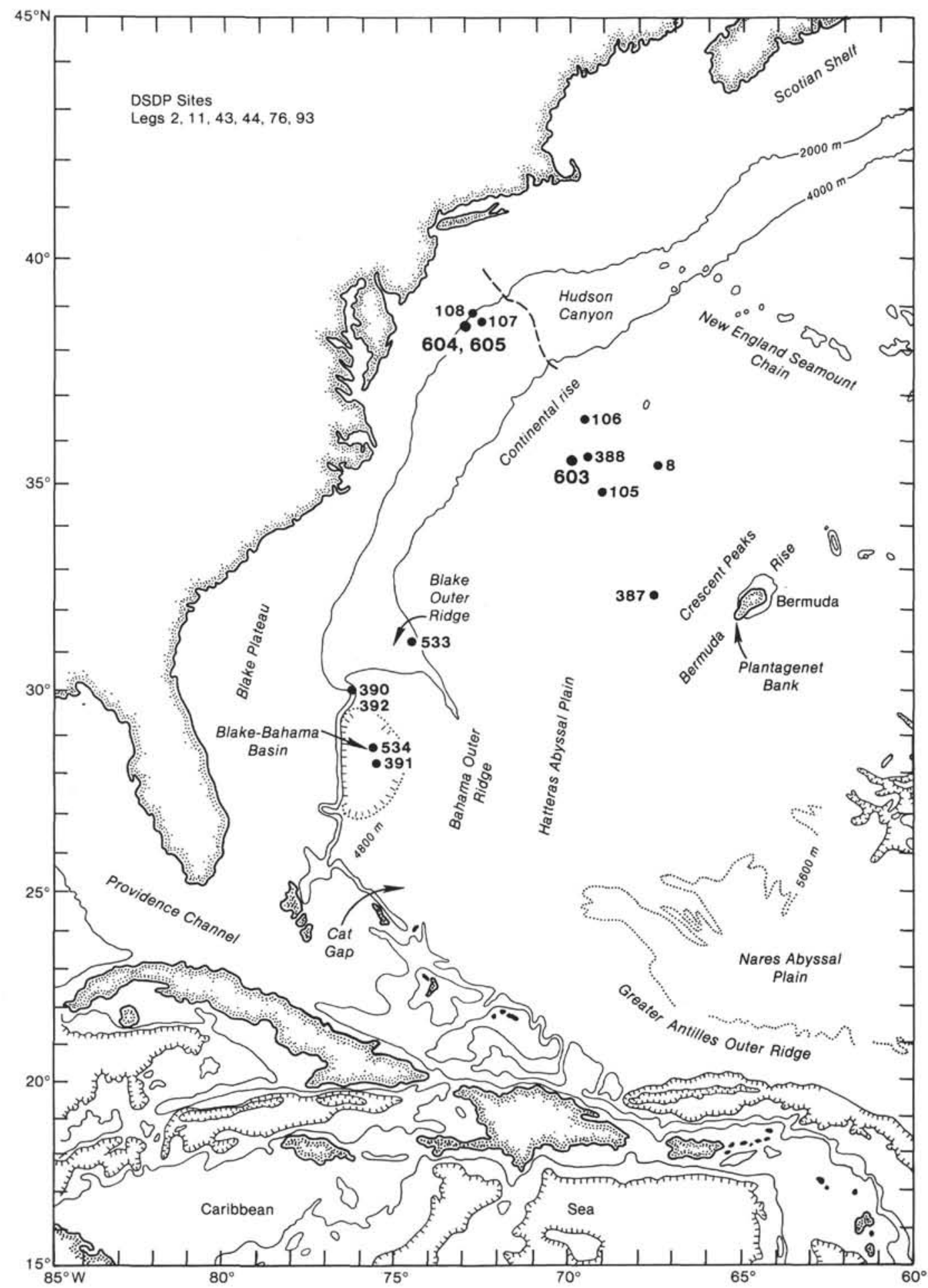

Figure 1. Location of DSDP sites and physiographic features of the North American Basin.

inclinations in the lower part of the section roughly indicate a magnetic polarity zonation, which becomes less distinct. In this chapter (see Fig. 6, later) the zones are numbered from 1-17.

For most samples, the intensity of the total NRM (Fig. 3) lies within the range $0.1-0.5 \mathrm{~mA} / \mathrm{m}$. This appeared to be sufficient to yield consistent results during the demagnetization treatment. The total NRM of the samples is usually a composite of remanences with different origins. In order to reveal the original remanence acquired when the sediment was deposited or shortly after, one generally subjects rock specimens to progressive demagnetization. Unfortunately, the soft clays and plastic boxes made thermal treatment impossible, so stepwise alternating magnetic field (AF) demagnetization was applied. First, a pilot series of samples was studied by a 15-step demagnetization treatment in alternating magnetic fields ranging up to $200 \mathrm{mT}$. The vector diagrams in Figure 4 are typical of the results obtained. A low-coercivity component was removed in alternating magnetic fields up to $25 \mathrm{mT}$. A more resistant and probably more stable component was progressively removed in alternating magnetic fields from 50 up to $150 \mathrm{mT}$.

On the basis of the results from the pilots series, a 10-step AF treatment was applied to most other samples. For samples with an ini- 


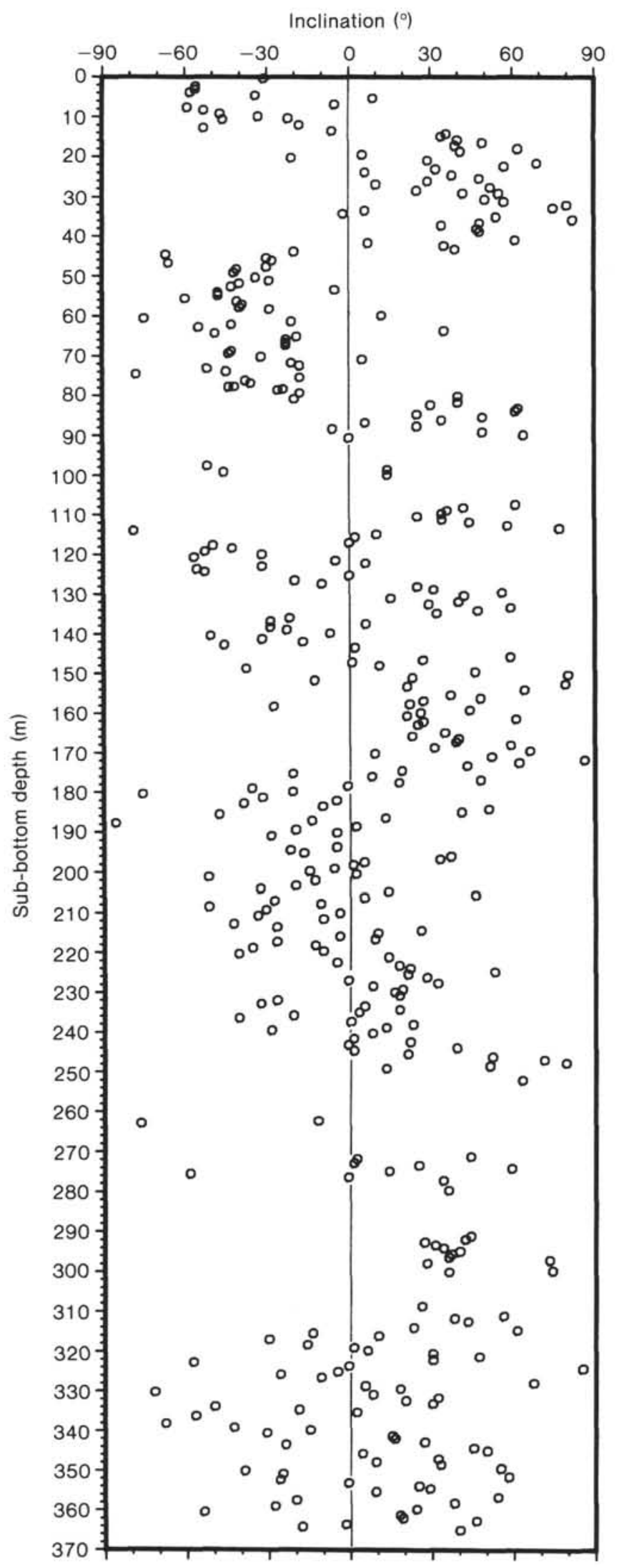

Figure 2. Inclinations of the total NRM directions of all late Cenozoic magnetostratigraphic samples from Hole 603C, Leg 93. Negative and positive inclinations represent reversed and normal polarities, respectively.

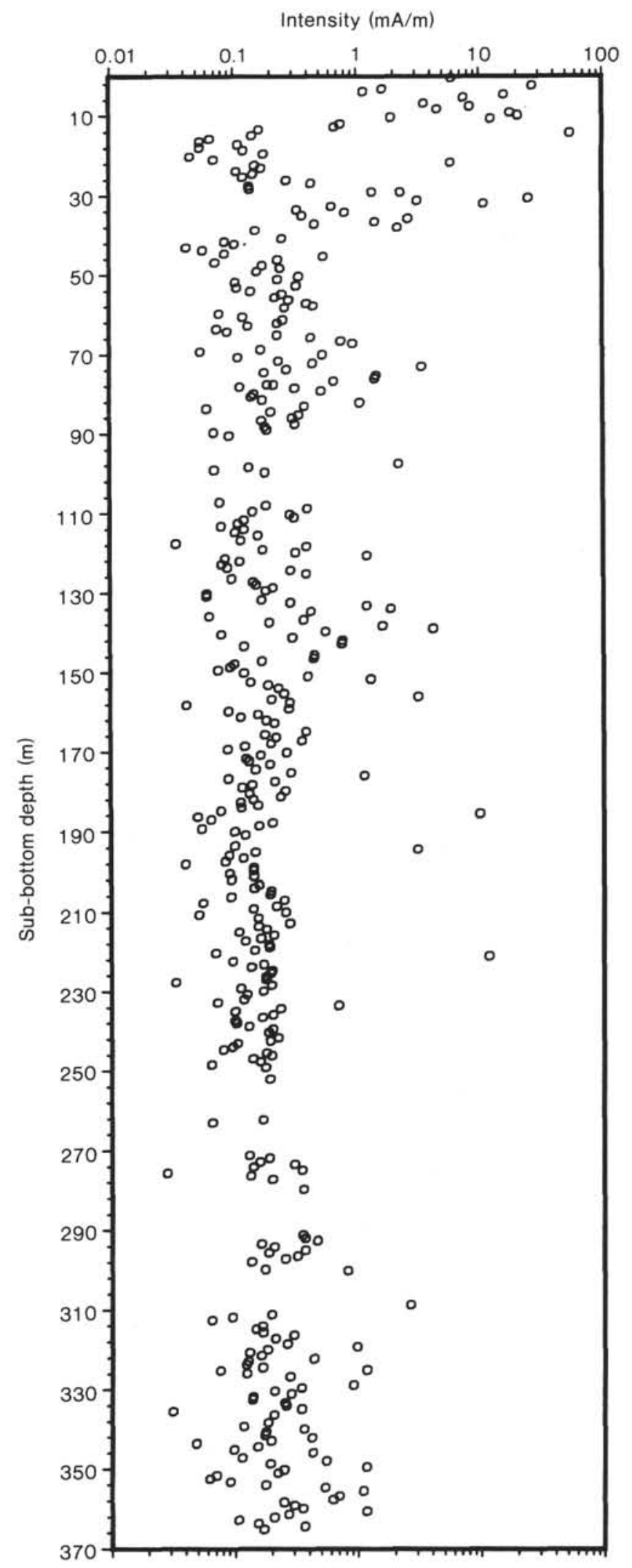

Figure 3. Intensities of the total NRM of the late Cenozoic section of Hole $603 \mathrm{C}$, Leg 93. The intensities are plotted on a logarithmic scale in $\mathrm{mA} / \mathrm{m}$. 
G. CANNINGA, J. D. A. ZIJDERVELD, J. E. VAN HINTE
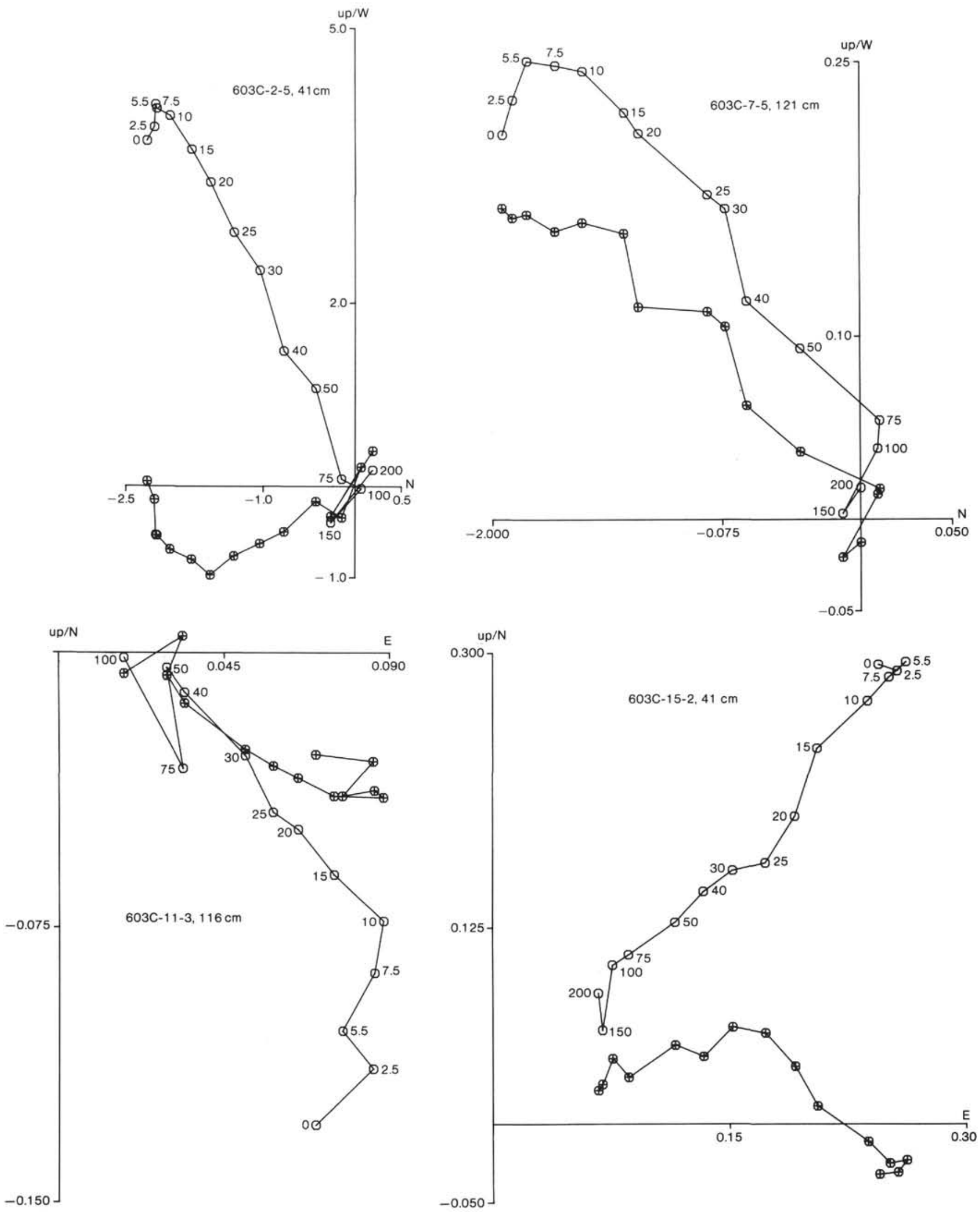

Figure 4. AF demagnetization diagrams of 12 samples. (Samples from Cores 2 to 28 are from the pilot series; see text.) Each diagram shows projections on the NS or EW vertical plane (open symbols) and on the horizontal plane (filled symbols) of vector end-points which represent the natural remanent magnetization at different demagnetization steps. At each step the intensity of the alternating magnetic field is indicated in $\mathrm{mT}$ near each vertical projection point. Units along axes in $\mathrm{mA} / \mathrm{m}$. 

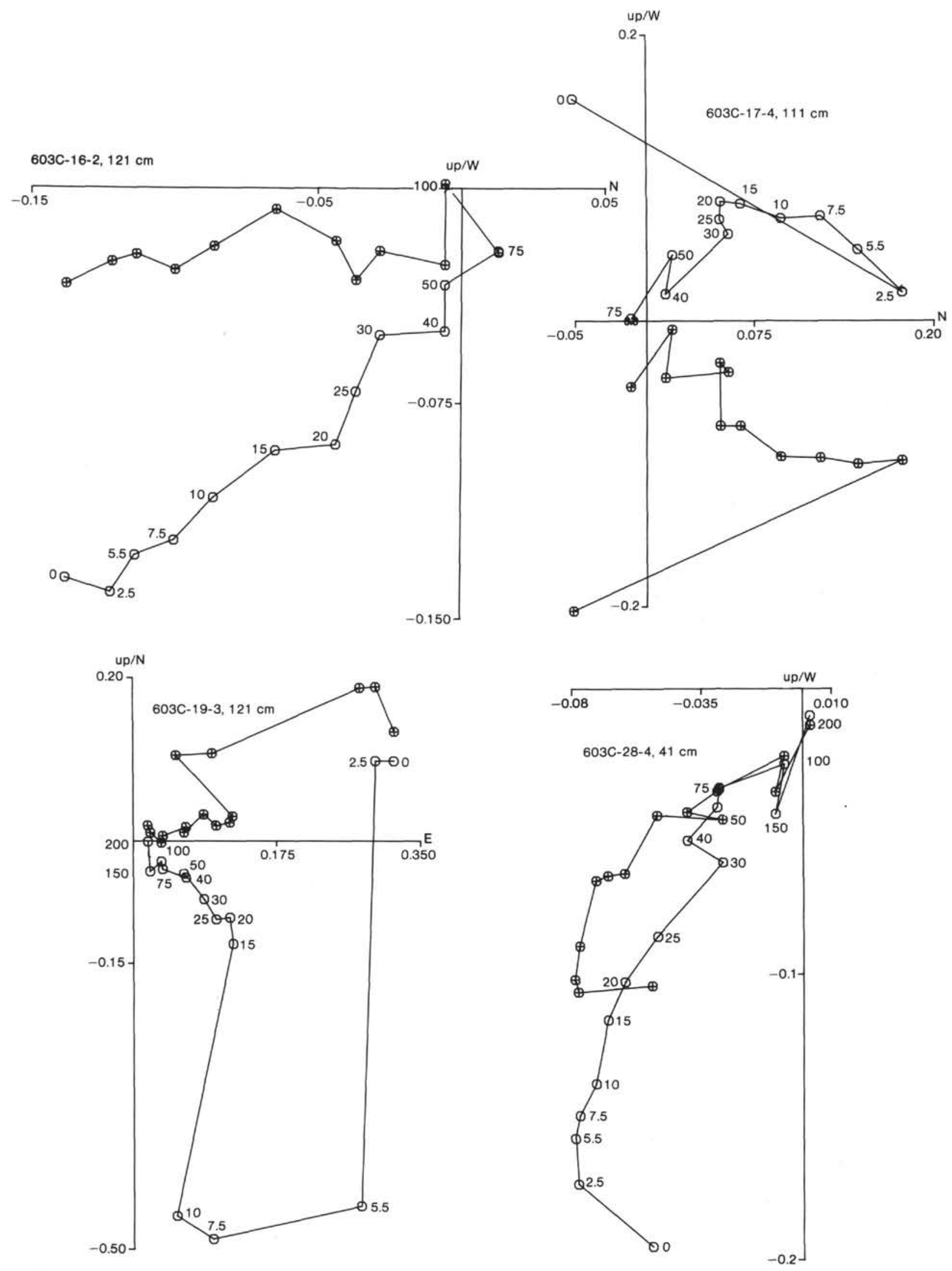

Figure 4 (continued). 


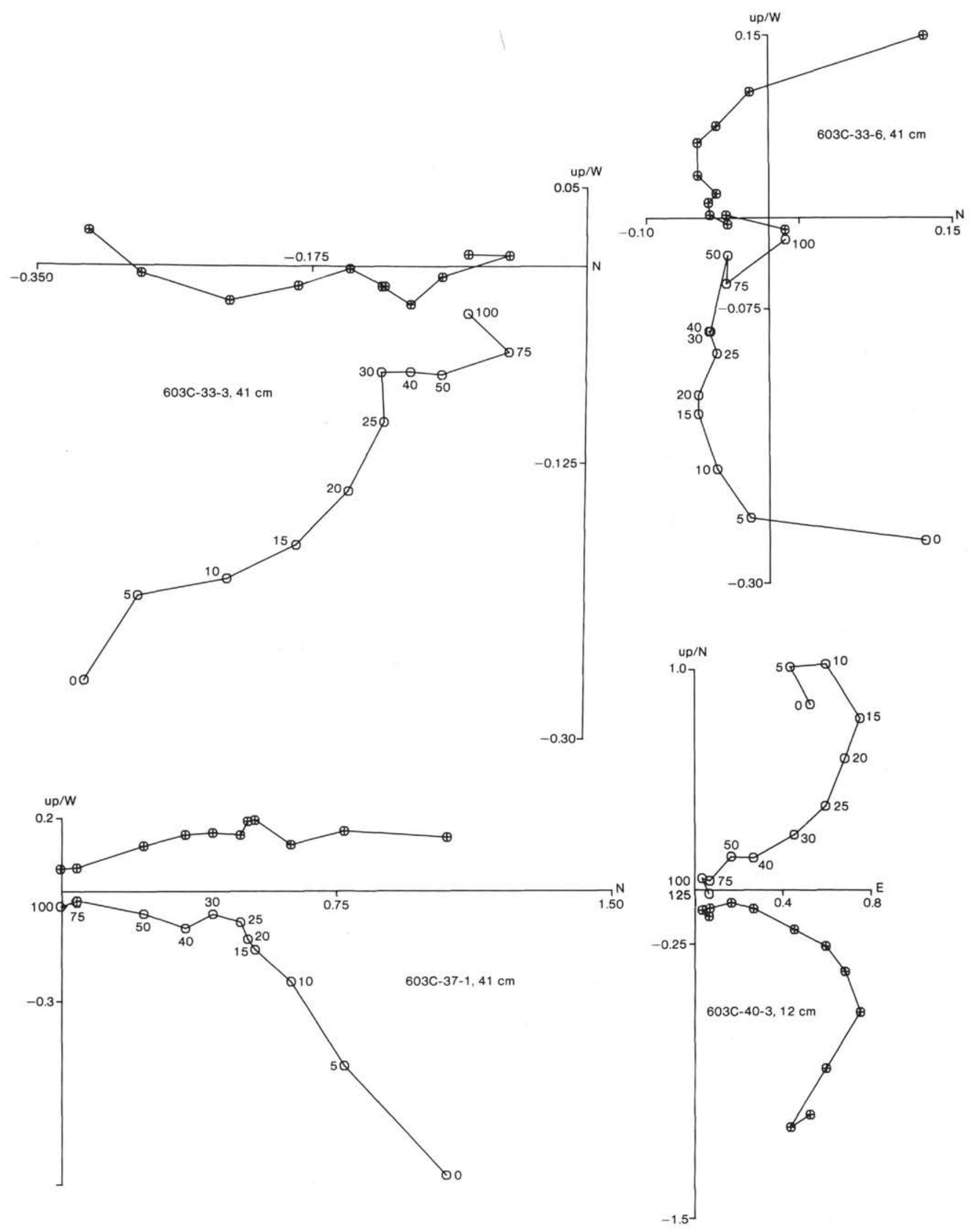

Figure 4 (continued). 
tial NRM intensity lower than $0.1 \mathrm{~mA} / \mathrm{m}$ the direction of the remanence remaining after the low-coercivity component had been removed could not be established with sufficient reliability. Therefore, samples preferred for AF treatment were those with a relatively high initial NRM intensity. However, care was taken to cover the entire section equally, with relatively higher sampling density at levels where there appeared to be a more frequent alteration of magnetic polarity zones. Most of the samples yielded useful results, although in the lower part of the section some of them lost $80-90 \%$ of their initial remanence in alternating magnetic fields of $30-40 \mathrm{mT}$, this is interpreted as representing predominantly secondary remanences. In that part of the section, a larger number of samples were demagnetized in order to preclude any ambiguity in establishing the polarity zonation.

\section{RESULTS AND CONCLUSIONS}

\section{Magnetic Properties and the Original NRM}

The remanent coercivity (Hcr) determined for a pilot series of 25 samples evenly distributed over the section showed very consistent values between 30 and $70 \mathrm{mT}$. These low Hcr values indicate that the magnetic remanence resides in fine-grained magnetite (e.g., Dankers, 1978). The shape of the normalized remanence acquisition curves for two samples shown in Figure 5 also indicates that the principal natural magnetic mineral present is magnetite (Lowrie and Heller, 1982). Magnetic saturation of up to $90 \%$ (or even $95 \%$ ) is achieved in a magnetic field of $0.3 \mathrm{~T}$ for all samples. The progressive AF demagnetization results revealed that the NRM of most samples is made up of a low-coercivity component and a higher-coercivity component. The low-coercivity component is most likely secondary and is probably of viscous origin.

When plotted against depth, the inclinations of the directions of the higher-coercivity component fall into zones with consistently positive or negative inclinations (Fig. 6) and thus typically reveal zones of alternating polarity. The presence of reversed polarities indicates that the higher-coercivity remanence must have been acquired before the last geomagnetic field reversal at $0.73 \mathrm{Ma}$; consequently, it has a high stability as well. Because there are no systematic differences in the magnetic properties of samples with opposite polarity, it is unlikely that the normal polarity zones are the result of some selective remagnetization process. On the contrary, both the reversed and normal natural higher-coercivity remanences seem to reside in the fine-grained magnetite in the samples and thus have similar high stability. This circumstantial evidence suggests that the higher-coercivity component most likely represents the original natural remanence acquired during or shortly after the deposition of the sediment. This conclusion, moreover, is supported by the result discussed in the following section, that the polarity zonation can be statistically correlated with the geomagnetic polarity time scale.

\section{Magnetostratigraphy and Correlation with the Geomagnetic Polarity Time Scale}

The inclinations of the higher-coercivity natural remanent component obtained by stepwise progressive AF demagnetization of samples evenly distributed over the entire sediment column from Hole 603C are plotted against depth in Figure 6. These inclinations reveal a se-

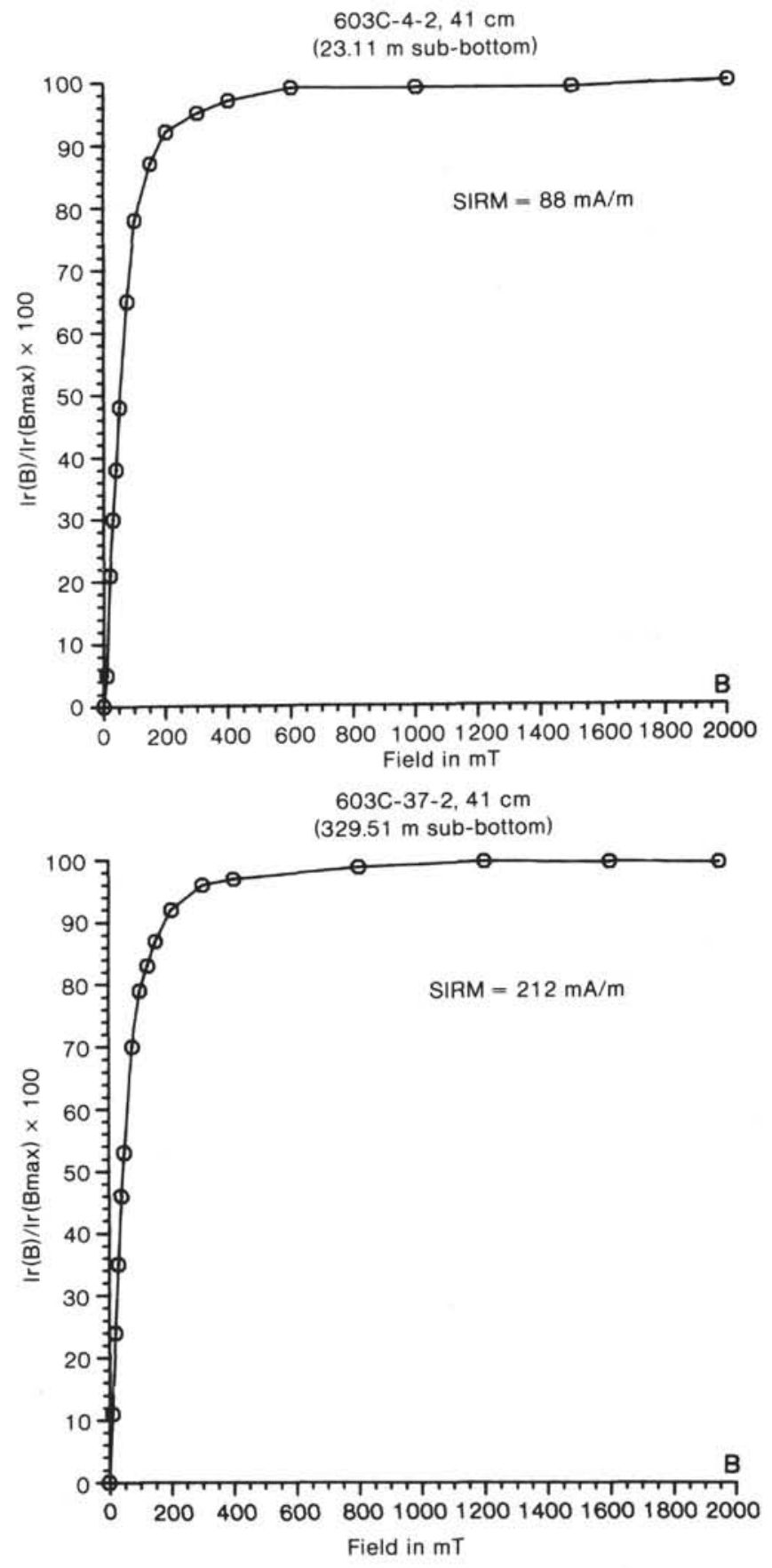

Figure 5. The normalized acquisition curves of the isothermal remanent magnetization (IRM) of two samples. These samples acquired $90 \%$ or more of their saturation IRM (SIRM) in a field of $0.3 \mathrm{~T}$, which indicates that the remanent magnetization resides mainly in magnetite (Lowrie and Heller, 1982).

quence of polarity zones. A positive correlatıun between the sequence of polarity zones and the geomagnetic polarity time scale would provide a precise time frame for the sedimentary sequence of Hole $603 \mathrm{C}$ and would also provide additional evidence for the primary nature of the NRM components studied. Although it seems to be common practice to identify the sequence of polarity zones by means of biostratigraphic datums observed within these zones, such an approach is basically incorrect, 


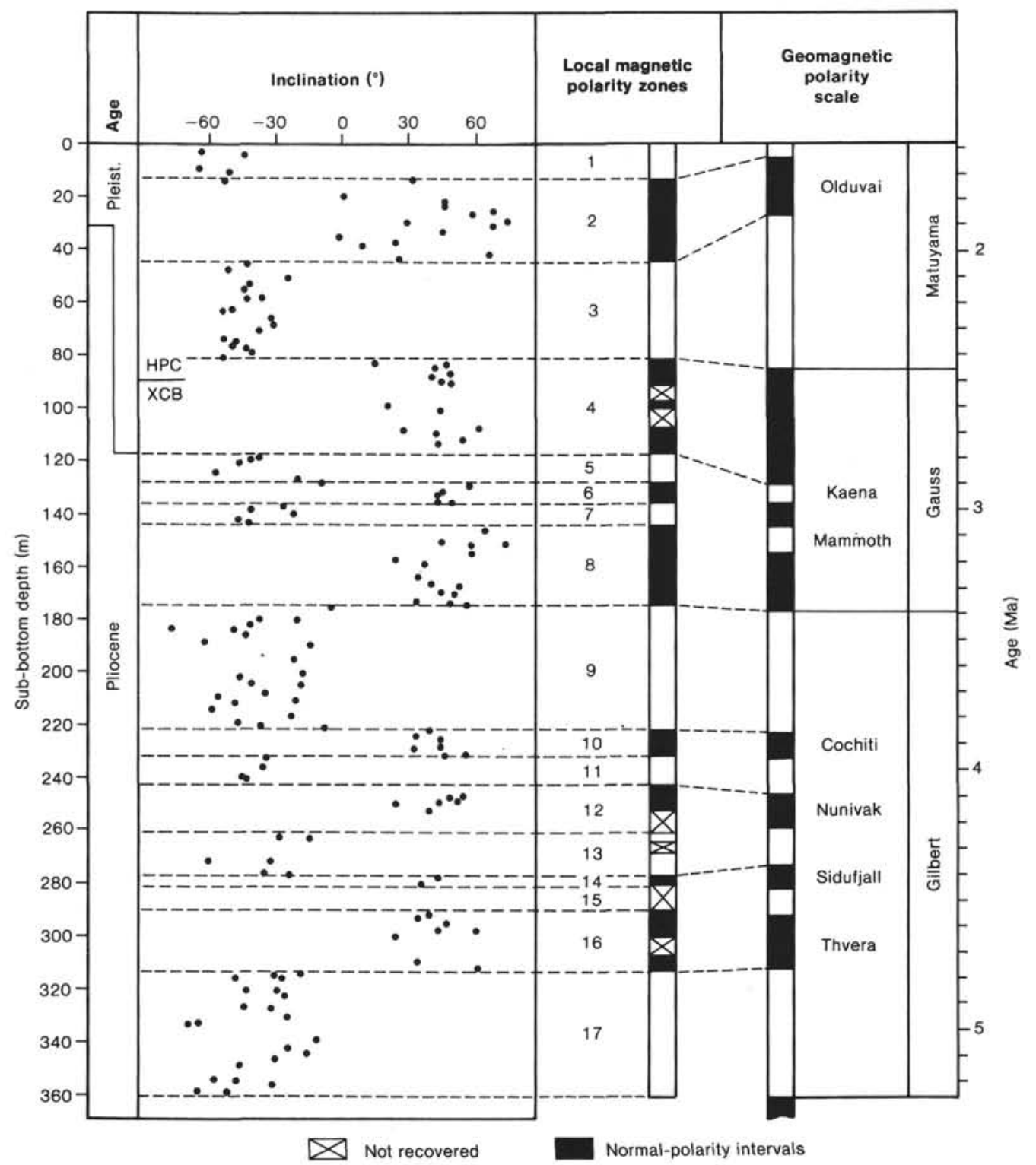

Figure 6. Late Cenozoic magnetostratigraphy of Hole 603C, Leg 93. The inclinations of the original natural remanences are derived from demagnetization diagrams (e.g., Fig. 4). A positive (negative) inclination represents a normal (reversed) polarity of the original natural remanence. The resulting polarity zonation is plotted to the right, along with the corresponding geomagnetic polarity time scale (Lowrie and Alvarez, 1981) and the correlation proposed in the text (dotted lines).

for it makes hardly any use of the magnetostratigraphic observations and inevitably leads to circular reasoning.

An independent and purely magnetostratigraphic procedure is to identify the sequence of polarity zones by the pattern formed by the different lengths of the successive zones. This is possible only if the accumulation rate during the interval discussed was reasonably uniform, and if no hiatuses are present. The uniformity requirement need not be very rigid. It does not require that an equal amount of sediment be deposited every year or even every thousand years, merely that over periods, say, of 50 to $100 \times 10^{3}$ year-the mean duration of a polarity zone-the accumulation rate was sufficiently uniform so that the characteristic pattern of duration for the successive polarity chrons has not become dis- torted beyond recognition. This relaxed criterion is more commonly realized in uniform marine sediments than is generally assumed.

In Hole $603 \mathrm{C}$, sediment recovery was complete between 107 and $251 \mathrm{~m}$ sub-bottom. In this part of the section, eight polarity transitions can be recognized, constituting the boundaries of polarity Zones 5 to 11 (Fig. 6). The sequence of lengths for Zones 5 to 11 can be correlated with the characteristic pattern of the geomagnetic polarity time scale (see e.g., Lowrie and Alvarez, 1981) by selecting the significantly high correlation coefficients from among the coefficients obtained for a series of correlations between the sequence of Zones 5 to 11 and every sequence of durations for each possible set of seven successive polarity chrons in the late Neogene part of 
the geomagnetic polarity time scale (Langereis et al., $1983 / 1984)$. If more than one significant correlation is found, then at least we know what the possible matches are, according to the magnetostratigraphic data, and can then turn to other stratigraphic evidence for a definite answer. Thus the potentialities and the limitations of magnetostratigraphy are revealed, the possible contributions of the different disciplines used in making the final correlation identified, and, if necessary, future corrections more easily made.

The correlation coefficients for 16 successive correlations of the sequence of Zones 5 to 11 in Hole $603 \mathrm{C}$ with the late Neogene part of the geomagnetic polarity time scale are presented in Figure 7. There appear to be two highly significant correlations: at reference position 8 , where polarity Zone 5 would correlate with the Kaena Subchron, and at reference position 16 , where polarity Zone 5 would correlate with the interval of reversed polarity between the Nunivak Subchron and the Sidufjall (C1) Subchron.

According to the Site 603 chapter, the sediments at the base of the section are of earliest Pliocene age. Since the Miocene/Pliocene boundary is commonly placed in the oldest part of the Gilbert Chron (Berggren and Van Couvering, 1974; Lowrie and Alvarez, 1981) a correlation at reference position 16 can be rejected, for it would tie polarity Zones 10 and 11 to the two younger polarity intervals of Chron 5.

Upper Pleistocene sediments are absent at Site 603, the top $31 \mathrm{~m}$ of the hole belonging to the lower Pleistocene Globorotalia truncatulinoides Zone. If we accept a magnetostratigraphic correlation at reference position 8 (Fig. 7), Zones 5 to 11 will correspond to the time period between the Kaena Subchron and the reversed-polarity interval that occurs between the Cochiti and the Nunivak subchrons. This period is entirely of Pliocene age and thus the magnetostratigraphic results are in agreement with the age based on planktonic foraminifers.

Where coring with the XCB began at $91 \mathrm{~m}$ downhole, there are two short intervals of about $7 \mathrm{~m}$ each that were not recovered. Assuming that sediments were continuously deposited during this interval and that the two gaps in coring fall within the same polarity zone, we may conclude that Zones 1 to 4 probably correlate, respectively, with the youngest long, reversed-polarity interval of the Matuyama Chron (in part), the Olduvai Subchron, the oldest long, reversed-polarity interval of the Matuyama Chron and the youngest normal-polarity interval of the Gauss Chron (Fig. 6). We can tentatively match Zones 12 to 17 with the geomagnetic polarity scale using the correlation just established for Zone 11 and the earliest Pliocene age determined for the base of the section by biostratigraphic data. These limit the correlation to the oldest six polarity intervals of the Gilbert Chron. The proposed correlation of the sequence is depicted in Figure 6; it is based on the assumption that the sediment accumulation rate for this series was of the same order as during the deposition of sediments in Zones 11 to 5 . The relatively long polarity Zone 17 may correlate with the long reversed interval of the Gilbert Chron, Zones 12 to 16 may correlate to that part of the geomagnetic

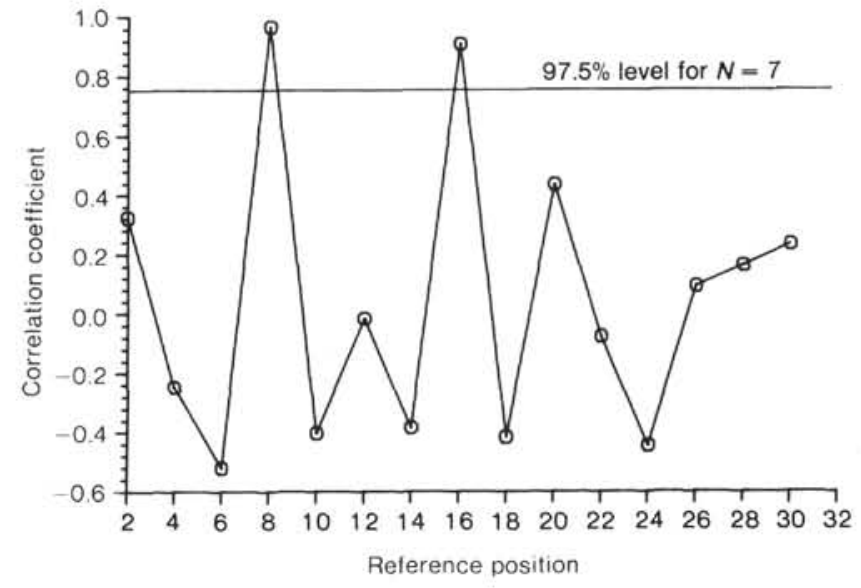

Figure 7. Correlation coefficients calculated for a series of correlations between the sequence of polarity Zones 5 to 11 (Fig. 6) in Hole $603 \mathrm{C}$ and the late Neogene geomagnetic polarity time scale of Lowrie and Alvarez (1981). The numbers on the horizontal axis represent reference positions on the geomagnetic polarity time scale for the youngest Zone 5 (Fig. 6); each successive reference position corresponds with an older reversed-polarity interval as the sequence of Zones 5 to 11 is moved along the geomagnetic polarity time scale. The point at which Zone 5 corresponds with the reversed interval between the Brunhes Chron and the Jaramillo Subchron is defined as No. 2, that is, the second polarity (sub)chron before the present. At position 8 , for example, Zone 5 corresponds with the Kaena Subchron. Significant positive correlation with $N=7$ (i.e., 7 polarity zones used) at a probability level of $97.5 \%$ is reached at a value of 0.754 for the correlation coefficient $R$.

polarity time scale from the Nunivak Subchron to the Thvera (C2) Subchron, and the unrecovered interval between $280 \mathrm{~m}$ and $290 \mathrm{~m}$ downhole may then contain the reversed-polarity interval between the Sidufjall and Thvera subchrons. On the other hand, Zone 15 is artificial, and the record may of course be incomplete. However, accumulation rates within Zones 12 to 16 vary in almost the same way as elsewhere in the section, and it seems reasonable to assume that the sedimentary record is complete.

\section{Sediment Accumulation Rates}

Using the correlations proposed above, sediment accumulation rates for each polarity zone have been calculated (Fig. 8). The average sediment accumulation rate for the series between $13.5 \mathrm{~m}$ and 312.5 downhole is $10.1 \mathrm{~cm} / 10^{3}$ year. Because only 3 polarity transitions were actually observed below $240 \mathrm{~m}$ downhole, the sedimentation rate for this segment of the column is shown as a dashed line in Figure 8.

Assuming that a relatively complete section has been cored and using an average accumulation rate of 10.1 $\mathrm{cm} / 10^{3}$ year, it is possible to locate by interpolation the unrecovered polarity transitions for Hole $603 \mathrm{C}$. By this method, the interpolated position for the boundary between Zones 12 and 13 is placed at $259 \mathrm{~m}$ downhole, and the boundary between zones 15 and 16 at $293.5 \mathrm{~m}$ downhole. However, $293.5 \mathrm{~m}$ downhole falls into the upper recovered part of Zone 16 and therefore is not correct for the boundary, which is more likely to have been located at $290 \mathrm{~m}$ downhole. This depth implies a sediment accumulation rate of $7.6 \mathrm{~cm} / 10^{3}$ year for Zones 


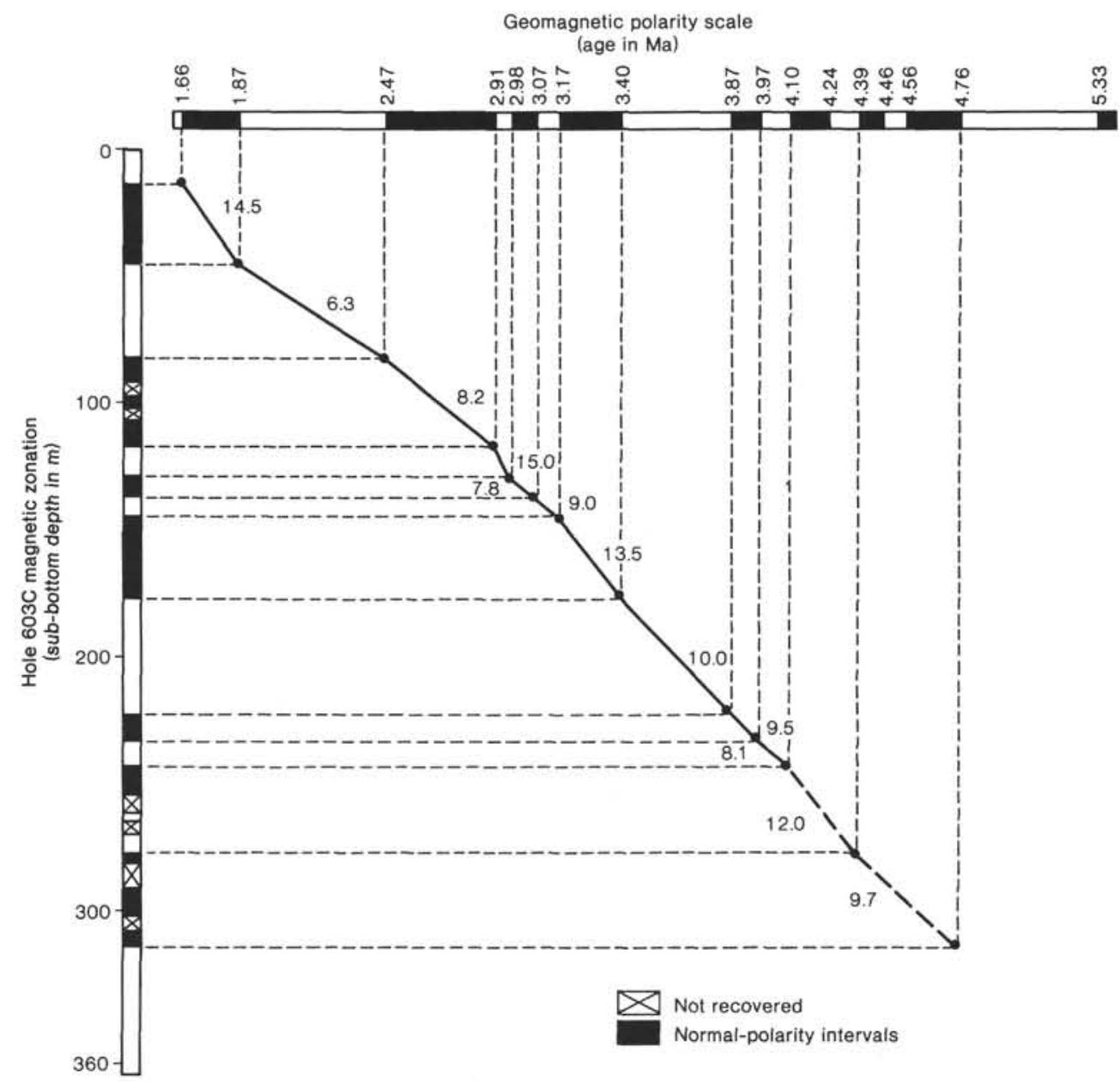

Figure 8. Comparison of Hole $603 \mathrm{C}$ local magnetozonation with the geomagnetic polarity time scale of Lowrie and Alvarez (1981). Also given are sediment accumulation rates in $\mathrm{cm} / 10^{3}$ years.

14 and 15 and an interpolated position for the boundary between them at $282 \mathrm{~m}$ downhole.

\section{Boundary Ages}

According to shipboard paleontologists, the first occurrence of Globorotalia truncatulinoides is located at approximately $31 \mathrm{~m}$ downhole. This biostratigraphic event has an age of $1.78 \mathrm{Ma}$, according to the correlation just deduced between the magnetic polarity zonation of Hole $603 \mathrm{C}$ and the geomagnetic polarity time scale (Lowrie and Alvarez, 1981).

The first occurrence of G. margaritae was not identified in Hole $603 \mathrm{C}$, and thus must be older than the base of our section (polarity Zone 17). With an average sedimentation rate of $10.1 \mathrm{~cm} / 10^{3}$ year, the extrapolated age of sediments at the bottom of the hole is $5.27 \mathrm{Ma}$; consequently, the first occurrence of $G$. margaritae should have been earlier than 5.27 Ma in the northwest Atlantic. Downward extrapolation of the same average sediment accumulation rate places the 5.3 Ma Miocene/Pliocene boundary at $369.03 \mathrm{~m}$ BSF.

\section{ACKNOWLEDGMENTS}

We wish to thank the DSDP shipboard scientists and technicians for their assistance during the collection of the samples. We gratefully acknowledge the instrumental support given by Dr. F. Heller and Prof. W. Lowrie of the Paleomagnetic Laboratory, ETH, Zürich.

\section{REFERENCES}

Berggren, W. A., and Van Couvering, J. A., 1974. Biostratigraphy, geochronology and Paleoclimatology of the last 15 million years in marine and continental sequences. Palaeogeogr., Palaeoclimatol., Palaeoecol., 16:1-216.

Dankers, P. H. M., 1978. Magnetic properties of dispersed natural iron-oxides of known grain-size [Ph.D. dissert.]. University of Utrecht, The Netherlands.

Gartner, S., 1977. Calcareous nannofossil biostratigraphy and revised zonation of the Pleistocene. Mar. Micropaleontol., 2:1-25.

Jansa, L. F., Enos, P., Tucholke, B. E., Gradstein, F. M., and Sheridan, R. E., 1979. Mesozoic-Cenozoic sedimentary formations of the North American Basin, western North Atlantic. In Talwani, M., Hay, W. W., and Ryan, W. B. F. (Eds.), Deep Drilling Results in the Atlantic Ocean: Continental Margins and Paleoenvironment: Washington D.C. (Am. Geophys. Un.), Maurice Ewing Ser., 3: $1-57$.

Langereis, C. G., Zachariasse, W. J., and Zijderveld, J. D. A., 1983/ 84. Late Miocene magnetobiostratigraphy of Crete. Mar. Micropaleontol., 8:261-281.

Lowrie, W., and Alvarez, W., 1981. One hundred million years of geomagnetic polarity history. Geology, 9:392-397.

Lowrie, W., and Heller, F., 1982. Magnetic properties of marine limestones. Rev. Geophys. Space Phys., 20:171-192.

Date of Initial Receipt: 27 March 1985

Date of Acceptance: 4 December 1985 